SOI: $1.1 /$ TAS $\quad$ DOI: $10.15863 /$ TAS

\section{International Scientific Journal Theoretical \& Applied Science}

p-ISSN: 2308-4944 (print) e-ISSN: 2409-0085 (online)

Year: 2015 Issue: 09 Volume: 29

Published: $30.09 .2015 \quad$ http://T-Science.org

SECTION 3. Nanotechnology. Physics.
Nfally DIEME

Laboratory of Semiconductors and Solar Energy, Department of Physics, Faculty of Science and Technology, Cheikh Anta DiopUniversity, Dakar, Senegal nfallydieme@yahoo.fr

Moustapha Sane

Laboratory of Semiconductors and Solar Energy, Department of Physics, Faculty of Science and Technology, Cheikh Anta DiopUniversity, Dakar, Senegal moustaphasane2003@yahoo.fr

Idrissa Fabe Barro Laboratory of Semiconductors and Solar Energy, Department of Physics, Faculty of Science and Technology, Cheikh Anta DiopUniversity,

Dakar, Senegal fabebarro@gmail.com

\title{
EFFECT OF THE DOPING RATE ON THE SHUNT AND SERIES RESISTANCES OF A SILICON SOLAR CELL
}

\footnotetext{
Abstract: In this study we used a mathematical approach to determine the shunt and series resistances of the parallel vertical junction solar cell. This approach rests primarily on the current-voltage characteristic of the solar cell under a multi-spectral illumination in static regime. Taking ground on a diffusion equation, the current-voltage characteristic is determined, the shunt and series resistance are deducted. The aim of this work is to show the effect of the base doping level on these two parameters. For that to be, we illustrated the profile of these two parameters for various doping rates.

Key words: Shunt resistance, series resistance, parallel junction, doping rate, temperature.

Language: English

Citation: Dieme N, Sane M, Barro IF (2015) EFFECT OF THE DOPING RATE ON THE SHUNT AND SERIES RESISTANCES OF A SILICON SOLAR CELL. ISJ Theoretical \& Applied Science 09 (29): 162-168.

Soi: http://s-o-i.org/1.1/TAS-09-29-31 Doi: crossef http://dx.doi.org/10.15863/TAS.2015.09.29.31
}

\section{Introduction}

When in its pure state, Silicon is not appropriate to produce electronic components because its conductivity is too low $\left(\approx 4.58 \times 10^{-6} \Omega^{-1} \mathrm{~m}^{-1}\right)[1-2]$. To increase its conductivity, a number of impurities were added. This process is called doping. The making of solar cells rests primarily on the doping of semiconductors. And there are several doping rates applicable to semiconductors. Solar cells contain two internal resistances called shunt and series resistances. The latter explain junction volume recombination and material resistivity, to name but a few [3].

The aim of this work is to investigate the influence of doping level on shunt ant series resistances. A mathematical approach based on the current-voltage characteristic was used to determine both resistances. They were ultimately studied according to the doping rate. Knowing the evolution of these quantities based on the doping rate is a good indicator for us to comment on the impact on the performance of solar cells.

\section{Modeling}

The parallel vertical junction silicon solar cell is presented in figure 1 . 


\begin{tabular}{|c|c|c|c|c|c|c|}
\hline Impact Factor: & $\begin{array}{l}\text { ISRA (India) } \\
\text { ISI (Dubai, UAF } \\
\text { GIF (Australia) } \\
\text { JIF }\end{array}$ & $\begin{array}{l}=1.344 \\
=0.829 \\
=0.356 \\
=1.500\end{array}$ & $\begin{array}{l}\text { SIS (USA) } \\
\text { PИНЦ (Russia) } \\
\text { ESJI (KZ) } \\
\text { SJIF (Morocco) }\end{array}$ & $\begin{array}{l}=0.912 \\
=0.179 \\
=1.042 \\
=\mathbf{2 . 0 3 1}\end{array}$ & ICV (Poland) & $=6.630$ \\
\hline
\end{tabular}

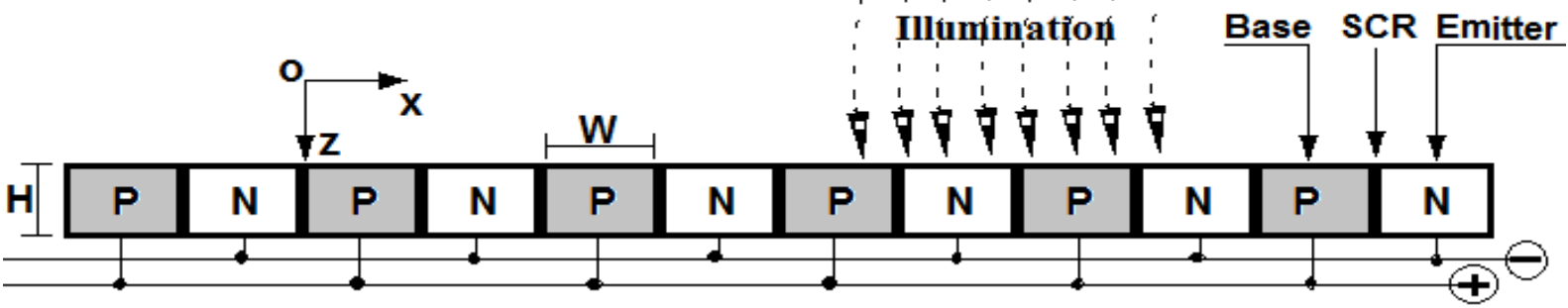

Figure 1 - Parallel vertical junction solar cell $(\mathrm{H}=0,02 \mathrm{~cm} ; \mathrm{W}=0,03 \mathrm{~cm})$.

When the solar cell is illuminated, there are simultaneously three major phenomena that happen: generation, diffusion and recombination [4].

These phenomena are described by the diffusion-recombination equation obtained with:

$$
\frac{\partial^{2} n(x)}{\partial x^{2}}-\frac{n(x)}{L^{2}}=-\frac{G_{n}}{D}
$$

$\mathrm{n}(\mathrm{x})$ and $\mathrm{L}$ are respectively the electrons density and diffusion length,

$\mathrm{D}$ is the diffusion constant [5]:

$$
D=\mu \cdot \frac{K}{q \sqrt{1+81 \frac{N b}{N b+3.2 \times 10^{18}}}} . T
$$

With $\mu$ is the mobility, $\mathrm{q}$ is the elementary charge, $\mathrm{k}$ the Boltzmann constant and $\mathrm{T}$ the temperature, $\mathrm{N}_{\mathrm{b}}$ is the base doping rate.

$\mathrm{Gn}=\mathrm{g}(\mathrm{z})+\mathrm{gth}$ is the carrier generation rate.

$\mathrm{g}(\mathrm{z})$ is the carrier generation rate at the depth $\mathrm{z}$ in the base and can be written as [6]:

$$
g(z)=\sum a_{i} e^{-b i z}
$$

$a_{i}$ and $b_{i}$ are obtained from the tabulated values of AM1.5 solar illumination spectrum.

gth is the thermal generation rate [7-8]:

$$
g_{t h}=c . n_{i}^{2}
$$

with

$$
n_{i}=A_{n} \cdot T^{\frac{3}{2}} \cdot \exp \left(\frac{E g}{2 K T}\right)
$$

$\mathrm{n}_{\mathrm{i}}$ refers to the intrinsic concentration of minority carriers in the base, $A_{n}$ is a specific constant of the material (

$$
\mathrm{A}_{\mathrm{n}}=3.87 \times 10^{16}
$$

for silicon) and $\mathrm{Eg}$ is the energy gap.

And the lifetime

$$
\tau=\frac{1}{C \cdot N b}
$$

$\mathrm{C}$ is the proportionality coefficient.

The solution of equation (1) is:

$$
n(x)=Y_{1} \sinh \left(\frac{x}{L}\right)+Y_{2} \cosh \left(\frac{x}{L}\right)+\sum \frac{a_{i}}{D} L^{2} e^{-b i z}+\frac{L^{2}}{D} C \cdot A_{n} \cdot T^{3} \cdot \exp \left(\frac{E g}{K T}\right)
$$

One determines the coefficients Y1 and Y2 by using the following boundary conditions:

at the junction $(x=0)$ :

$$
\left.\frac{\partial n(x)}{\partial x}\right|_{x=0}=\frac{S_{f}}{D} n(0)
$$

$\mathrm{Sf}$ is the recombination velocity at the junction. in the middle of the base $(x=W / 2)$ :

$$
\left.\frac{\partial n(x)}{\partial x}\right|_{x=\frac{w}{2}}=\mathbf{O}
$$

The photocurrent Jph is given by [8-9-10]:

$$
J_{p h}=\left.q D \frac{\partial n(x)}{\partial x}\right|_{x=\mathbf{0}}
$$
9-10]:

The photovoltage at the junction is given by [8- 


\begin{tabular}{|c|c|c|c|c|c|c|}
\hline Impact Factor: & $\begin{array}{l}\text { ISRA (India) } \\
\text { ISI (Dubai, UAE } \\
\text { GIF (Australia) } \\
\text { JIF }\end{array}$ & $\begin{array}{l}=1.344 \\
=0.829 \\
=0.356 \\
=1.500\end{array}$ & $\begin{array}{l}\text { SIS (USA) } \\
\text { PИНЦ (Russia) } \\
\text { ESJI (KZ) } \\
\text { SJIF (Morocco) }\end{array}$ & $\begin{array}{l}=0.912 \\
=0.179 \\
=1.042 \\
=2.031\end{array}$ & ICV (Poland) & $=6.630$ \\
\hline
\end{tabular}

$$
\mathrm{V}_{\mathrm{ph}}=\frac{k \cdot T}{q} \cdot \ln \left(N_{B} \cdot \frac{n(0)}{n_{i}^{2}}+1\right)
$$

The current-voltage characteristic is illustrated by the Figure 2 below.

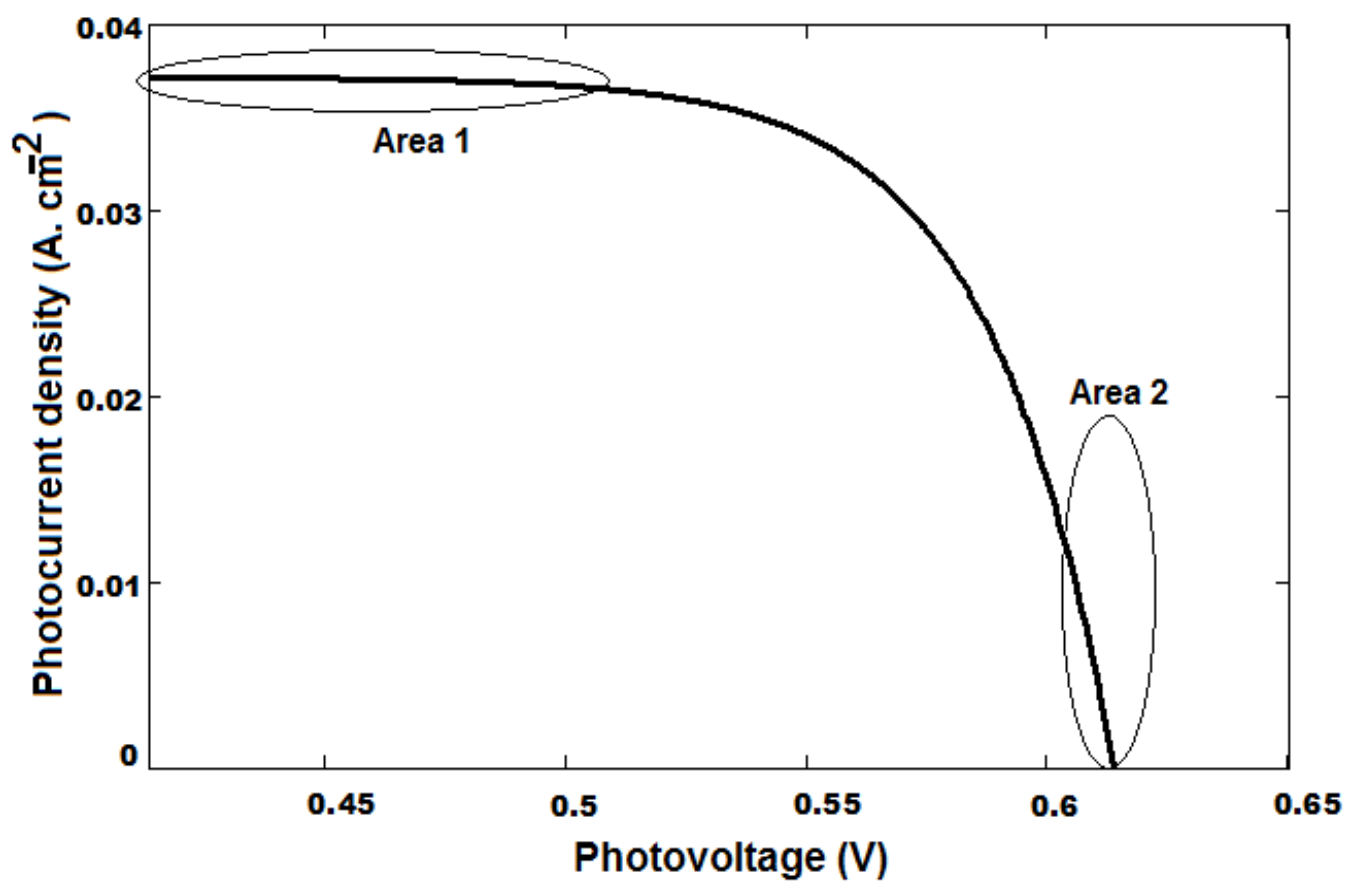

Figure 2 - Characteristic current -voltage $\left(\mathrm{z}=10^{-3} \mathrm{~cm}\right)$.

This characteristic presents two very significant zones:

Area 1 of Figure 2 seems to be linear. It can be matched with the high values of photocurrent. This is called the vicinity of the short-circuit operation point.
Figure 3 below is obtained on drawing the photocurrent curve according to photovoltage low values. 


\begin{tabular}{|c|c|c|c|c|c|c|}
\hline Impact Factor: & $\begin{array}{l}\text { ISRA (India) } \\
\text { ISI (Dubai, UAE } \\
\text { GIF (Australia) } \\
\text { JIF }\end{array}$ & $\begin{array}{r}=1.344 \\
=0.829 \\
=0.356 \\
=1.500\end{array}$ & $\begin{array}{l}\text { SIS (USA) } \\
\text { PИНЦ (Russia) } \\
\text { ESJI (KZ) } \\
\text { SJIF (Morocco) }\end{array}$ & $\begin{array}{l}=0.912 \\
=0.179 \\
=1.042 \\
=\mathbf{2 . 0 3 1}\end{array}$ & ICV (Poland) & $=6.630$ \\
\hline
\end{tabular}

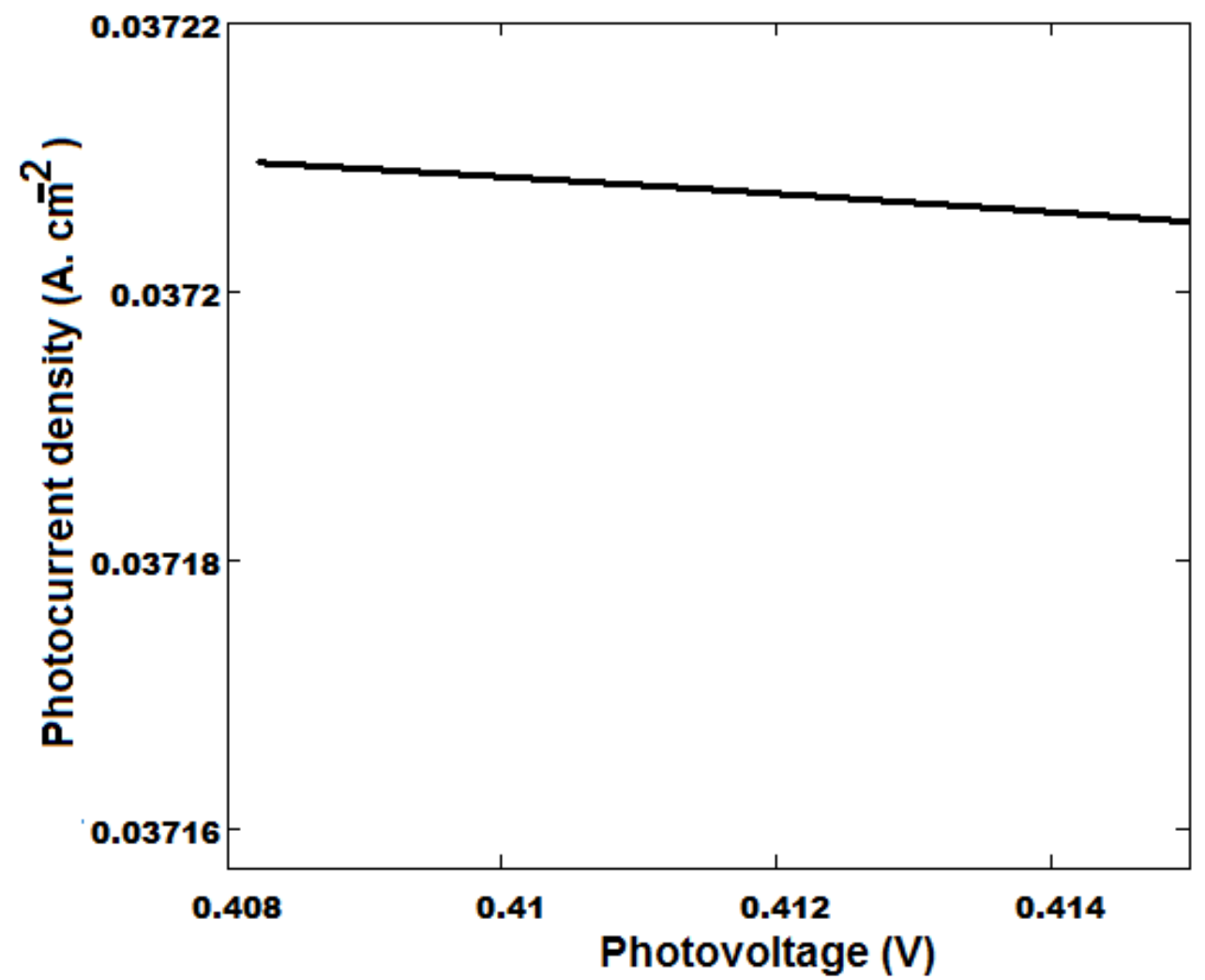

Figure 3 - Photocurrent versus photovoltage low values $\left(z=10^{-3} \mathrm{~cm}\right)$.

It can be noticed that the curve of photocurrent versus photovoltage low values is an affine equation:

$$
J p h=B-G \cdot V p h
$$

With

B: the initial intercept; Jph: current density, Vph: photovoltage; $\mathrm{G}$ is the line directing coefficient

In matter of Physics, this means that in a shortcircuit situation, the solar cell behaves like a current generator with $\mathrm{G}$ as an internal admittance and $\mathrm{B}$ the generated current density. Consequently:

$\mathrm{B}=\mathrm{Jsc}$ : short-circuit current density and the reverse of admittance $\mathrm{G}$ is impedance (resistance in
D.C. current). This internal resistance is called shunt resistance $(\mathrm{Rsh}=1 / \mathrm{G})$.

From the equation (13), the expression of Rsh is:

$$
R s h=\frac{V p h}{J c c-J p h}
$$

Area 2 of figure 2 seems to be linear. It can be matched with the high values of photovoltage. This is called the vicinity of the open-circuit operation point.

Figure 4 below is obtained on drawing the photovoltage curve according to photocurrent low values. 


\begin{tabular}{|c|c|c|c|c|c|c|}
\hline Impact Factor: & $\begin{array}{l}\text { ISRA (India) } \\
\text { ISI (Dubai, UAE } \\
\text { GIF (Australia) } \\
\text { JIF }\end{array}$ & $\begin{array}{l}=1.344 \\
=0.829 \\
=0.356 \\
=1.500\end{array}$ & $\begin{array}{l}\text { SIS (USA) } \\
\text { PИНЦ (Russia) } \\
\text { ESJI (KZ) } \\
\text { SJIF (Morocco) }\end{array}$ & $\begin{array}{l}=0.912 \\
=0.179 \\
=1.042 \\
=2.031\end{array}$ & ICV (Poland) & $=6.630$ \\
\hline
\end{tabular}

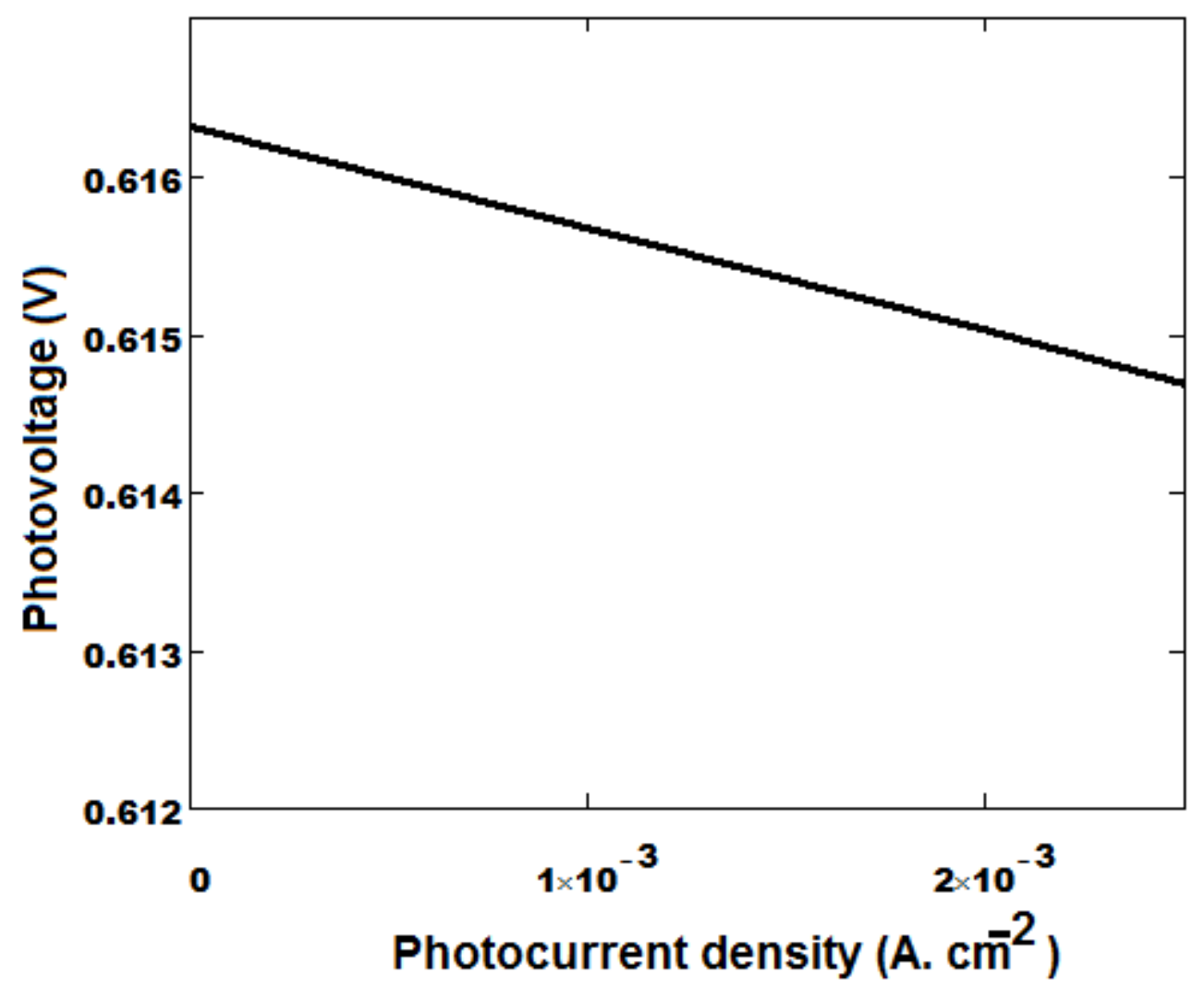

Figure 4 - Photovoltage versus Photocurrent low values $\left(z=10^{-3} \mathrm{~cm}\right)$.

It can be noticed that the curve of photovoltage versus photocurrent low values is an affine equation:

$$
V p h=C-r . J p h
$$

With

$\mathrm{C}$ :the ordinate in the beginning

$\mathrm{R}$ :is the directing coefficient of the right-hand side

In physics, that means that in open-circuit situation, the solar cell behaves like a voltage generator with $\mathrm{r}$ intern resistance and $\mathrm{C}$ electromotive force.

In matter of Physics, this means that in an opencircuit situation, the solar cell behaves like a voltage generator with $\mathrm{r}$ as an internal resistance and $\mathrm{C}$ the electromotive force. Comparatively:

This resistance is called series resistance $r=R s$.

$\mathrm{C}=\mathrm{Voc}$ : open-circuit photovoltage

From the equation (14) the expression of the series resistance is:

$$
R_{S}=\frac{V c o-V p h}{I p h}
$$

\section{Results and discussion}

The evolution of the shunt resistance versus temperature for various doping rates is illustrated by the following Figure5.

It can be noticed that the resistance shunt (Rsh) decreases irreversibility according to temperature. This decrease is all the more important as the doping rate is low. Rsh is maintained at the junction to be opposed to current leakage and volume recombinations. A high doping rate decreases the mobility of charge carriers. Thus, current leakage and volume recombinations decrease with the increase in the doping rate. A high doping rate favors the storage of charge carriers. Consequently, it can be said that the solar cell developed an internal resistance (known as shunt resistance) to be opposed to current leakage and volume recombinations.

The profile of the series resistance versus temperature for various doping rates is illustrated by Figure 6 below. 


\begin{tabular}{|c|c|c|c|c|c|c|}
\hline Impact Factor: & $\begin{array}{l}\text { ISRA (India) } \\
\text { ISI (Dubai, UAE } \\
\text { GIF (Australia) } \\
\text { JIF }\end{array}$ & $\begin{array}{l}=1.344 \\
=0.829 \\
=0.356 \\
=1.500\end{array}$ & $\begin{array}{l}\text { SIS (USA) } \\
\text { PUHЦ (Russia) } \\
\text { ESJI (KZ) } \\
\text { SJIF (Morocco) }\end{array}$ & $\begin{array}{l}=0.912 \\
=0.179 \\
=1.042 \\
=2.031\end{array}$ & ICV (Poland) & $=6.630$ \\
\hline
\end{tabular}

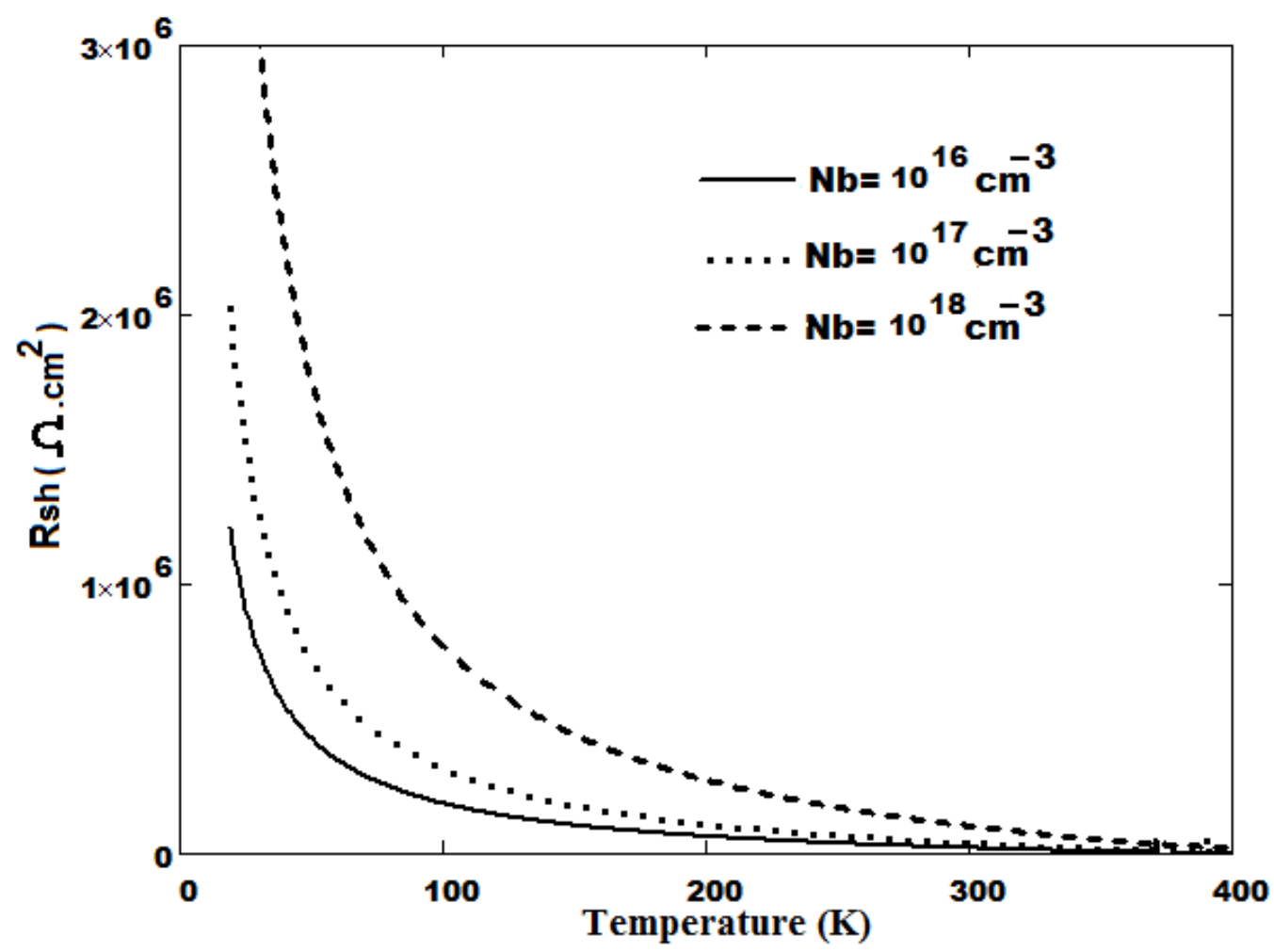

Figure 5 - Shunt resistance versus temperature for various doping rates $\left(\mathrm{z}=10^{-3} \mathrm{~cm}\right)$.

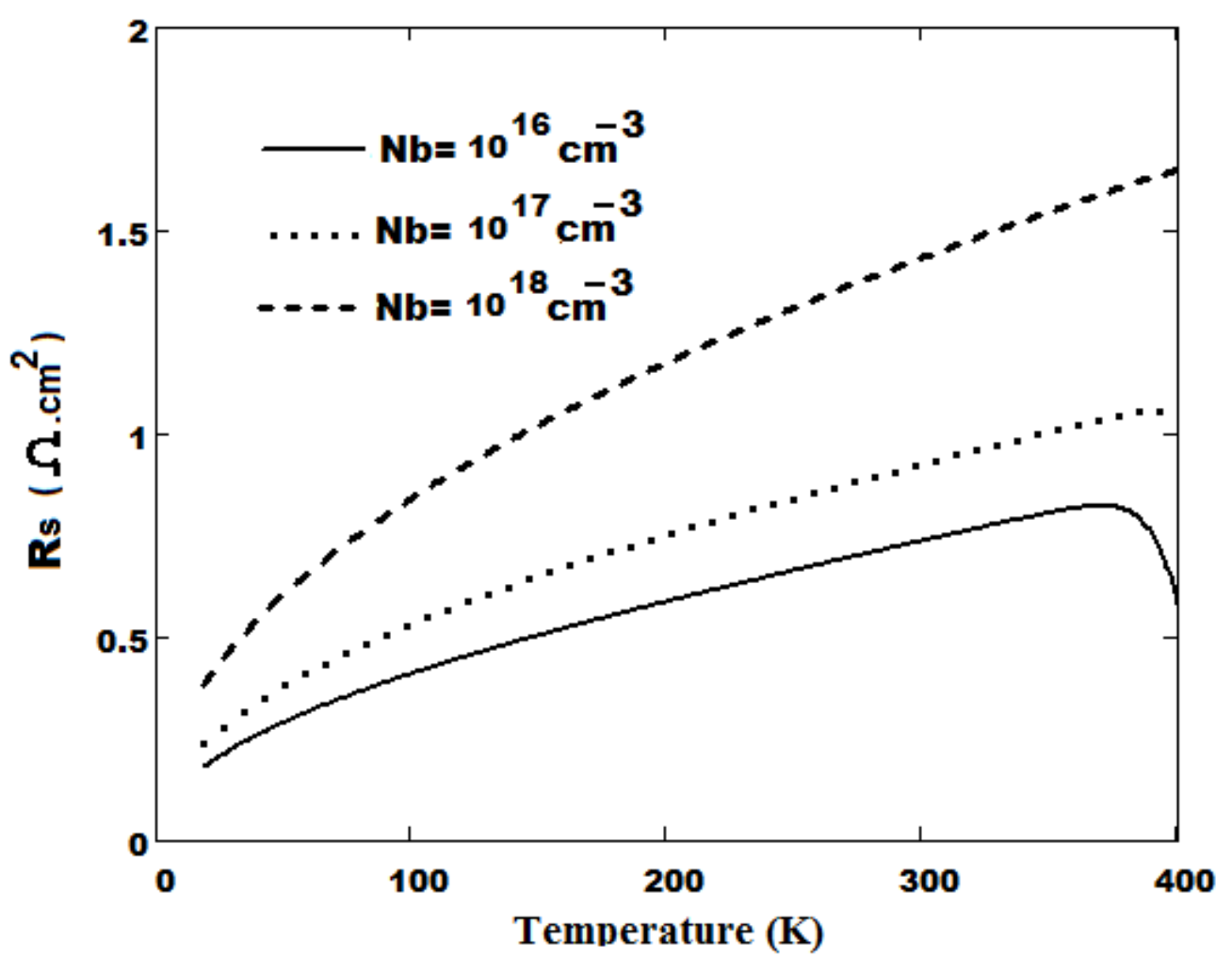

Figure 6 - Series resistance versus temperature for various doping rates $\left(\mathrm{z}=10^{-3} \mathrm{~cm}\right)$. 


\begin{tabular}{|c|c|c|c|c|c|}
\hline Impact Factor: & $\begin{array}{l}\text { ISRA (India) } \\
\text { ISI (Dubai, UAE } \\
\text { GIF (Australia) } \\
\text { JIF }\end{array}$ & $\begin{array}{l}=1.344 \\
=0.829 \\
=0.356 \\
=1.500\end{array}$ & $\begin{array}{l}\text { SIS (USA) } \\
\text { PИНЦ (Russia } \\
\text { ESJI (KZ) } \\
\text { SJIF (Morocco }\end{array}$ & $\begin{array}{l}=0.912 \\
=0.179 \\
=1.042 \\
=\mathbf{2 . 0 3 1}\end{array}$ & ICV (Poland) \\
\hline
\end{tabular}

With temperature, several electrons cross the junction. As it opposes the diffusion of charge carriers, the latter creates, in parallel with the electric field, an internal resistance known as series resistance, which increases in accordance with the flow of electrons that cross the junction. It should be added that increase in the doping rate increases the height of the junction potential barrier. Thus the flow of carriers decreases because several electrons do not have enough energy to jump the barrier. This situation is synonymous with great resistivity developed by the doped material.

\section{Conclusion}

In this study a mathematical approach was used to determine the shunt and series resistances of the parallel vertical junction solar cell. This approach rests primarily on the current-voltage characteristic of the solar cell. The evolution of these resistances for various doping rates shows that a high doping rate increases the resistivity of the material to be opposed to the diffusion of the charge carriers. It also favors the decrease of the electrons diffusion.

\section{References:}

1. Valkov S (1994) Electronique analogique: Edition Castéilla, Collection A. Capliez, 1994.

2. Levy F (1995) Traité des matériaux 18 : Physique et technologie des semiconducteurs: Presses Polytechniques et Universitaires Romandes, 1995.

3. Dieme N, Seibou B, El Moujtaba, MAO, Gaye I, Sissoko G (2015) Thermal behavior of a parallel vertical junction Silicon photocell in static regime by study of the series and shunt resistances under the effect of temperature, Int. J. In. Sci. Eng. Technol. 2015, 2, 433-437.

4. Dieme N, Zoungrana M, Mbodji S, Diallo HL, Ndiaye M, Barro FI, Sissoko G (2014) Influence of Temperature on the Electrical Parameters of a Vertical Parallel Junction Silicon Solar Cell under Polychromatic Illumination in Steady State, Res.J. App. Sci. Eng. Technol. 2014, 7, 2559-2562.

5. Faye K, Gaye I, Gueye S, Tamba S, Sissoko G (2014) Effect of Doping Level of a Silicon Solar Cell Under Back Side
Illumination, Cur. Tre. Technol. Sci. 2014, 3, 365-371.

6. Barro FI, Sane M, Zouma B (2015) On the capacitance of crystalline silicon solar cells in steady state, Turk. J. Phy. 2015, 39, 122127.

7. Sze M, Kwok K (2007) Ng. Physics of Semiconductor Devices, Third Edition, John Wiley \& Sons, 2007.

8. Dieme N (2015) Study of the Electrons Density in the Base of the Parallel Vertical Junction Solar Cell Under the Influence of the Temperature, Amer. J. Opt. Phot. 2015, 3, 13-16.

9. Dieme N, Sane M, Barro IF (2015) Photocurrent and photovoltage under influence of the solar cell thickness, ISJ Theor. Appl. Sci. 2015, 07, 1-6.

10. Diallo LH, Dieng B, Ly I, Dione MM, Wereme A, Ndiaye M, Sissoko G (2012) Determination of the recombination and electrical parameters of a vertical multijunction silicon solar cell, Res. J. Appl. Sci. Eng. Technol. 2012, 4, 26262631. 